\title{
Transplantation of Mitral Allograft into the Tricuspid Position - a Sheep Experimental Model
}

\author{
A. MOKRÁČEK ${ }^{1}$, J. HLUBOCKÝ $^{2}$, J. BURKERT $^{2}$, J. VOJÁČEK ${ }^{2}$, M. ŠULDA ${ }^{1}$, \\ M. VAMBERA ${ }^{1}$, J. KURSA ${ }^{3}$, V. KROUPOVÁ 3 , P. KOBYLKA ${ }^{4}$, J. ŠPATENKA $^{2}$ \\ ${ }^{1}$ Cardiac Surgery Department, Regional Hospital České Budějovice Inc. \\ ${ }^{2}$ Transplant Centre, University Hospital Motol, Prague \\ ${ }^{3}$ University of South Bohemia České Budějovice, Faculty of Agriculture, Department of Anatomy and \\ Physiology of Farm Animals \\ ${ }^{4}$ Institute of Hematology and Blood Transfusion, Prague
}

Received January 22, 2007

Accepted February 14, 2008

\begin{abstract}
Mokráček A., J. Hlubocký, J. Burkert, J. Vojáček, M. Šulda, M. Vambera, J. Kursa, V. Kroupová, P. Kobylka, J. Špatenka: Transplantation of Mitral Allograft into the Tricuspid Position - a Sheep Experimental Model. Acta Vet. Brno 2008, 77: 89-95.

Our research was focused on finding the optimal technique of cryopreserved mitral allograft implantation into the tricuspid valve position in a sheep experiment. We prepared 20 cryopreserved mitral valve allografts preoperatively. These were implanted into the tricuspid position in 20 sheep via right thoracotomy, using extracorporeal circulation with cardioplegic heart arrest. We consider the transventricular papillary muscle fixation to be the best technique for obtaining optimal allograft geometry and long-term durability. We evaluated the valve function by epicardial echo before and after implantation, respectively. The findings were confirmed by haemodynamic measurements as well. It was proved that mitral allografts, harvested, processed, and stored according to the Cardiovascular Tissue Bank Protocol remained mechanically strong enough for implantation into the tricuspid position. It was demonstrated that the mitral allograft transplantation into the tricuspid position is feasible. The immediate postoperative haemodynamic performance was excellent in all animals. The mid-term results are currently being evaluated prior to the possible application of the technique in humans at our institutions.
\end{abstract}

Mitral homograft, epicardial echocardiography, cryopreservation, extracorporeal circulation, tissue banking, blood transfusion, sheep

After half a century of history, cardiac valve surgery has become routine in developed countries. From the very beginning, mechanical and biological heart valve substitutes were designed, investigated and developed in parallel. Biological valve prostheses were simultaneously perfected in two lines - the commercial interest was focused mainly on the xenograft heart valve substitute construction, while much scientific interest was paid to the clinical use of allograft heart valves in smaller cohorts of patients. Currently about $49 \%$ of patients requiring heart valve replacement receive mechanical valve substitute and about $49 \%$ have their valves replaced by xenograft. Only $2 \%$ of diseased valves are being replaced by allografts. Nevertheless, none of these types represent an ideal valve substitute. Mechanical valve prostheses are durable, but thrombogenic, e.g. patients need anticoagulation therapy (with related complications) for the rest of life. To the contrary, biological valve substitutes are not thrombogenic, anticoagulation therapy is not necessary, but tissue degeneration remains the main reason for structural valve deterioration.

Extensive research is still in progress in many commercial as well as academic centres, when the animal modelling has become a routine to assess the short-term haemodynamic characteristics as well as long-term results of new models of prostheses as well as new and/ or modified surgical implantation techniques. Veterinary surgeons have become standard

Address for correspondence:

MUDr. Jaroslav Špatenka, PhD

Head, Transplant Centre, University Hospital Motol

V Uvalu 84, 15006 Prague 5

Czech Republic

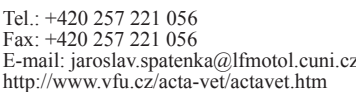

Tel.: +420257221056

Fax: +420257221056

E-mail: jaroslav.spatenka@lfmotol.cuni.cz

http://www.vfu.cz/acta-vet/actavet.htm 
and obligatory team members in animal research. Experimental operations with the use of extracorporeal circulation evaluating the medium and/or long-term animal survival need a high level of veterinary medical care. Therefore, we consider it essential to provide detailed information to those who are selecting suitable experimental animals and care for them after a serious surgical intervention.

The aortic allograft has been used for more than 40 years and it has been accepted by many surgeons as well as cardiologists. In certain indications it is considered as treatment of choice. The history of the mitral allograft (MA) has been completely different. Although experiments with MAs were reported even earlier than those with the aortic allograft, MA was never widely used in clinical practice. (Bodnar 1994; Hubka et al. 1966)

The reasons were following:

- MA must be implanted with its subvalvular apparatus, including papillary muscles, which is technically difficult.

- Very often, MA was used in the mitral position. Due to exposure to the high-pressure system, papillary muscle dehiscence or rupture of chordae tendineae was relatively frequent.

- Long-term results - even when the operation was carried out by extremely experienced surgeons - were disappointing.

- At the same time, the improvement of mitral valve repair techniques together with the availability of high quality mechanical and xenograft prosthetic valves shifted the attention of cardiac surgeons away from MA.

The situation was rather different concerning tricuspid valve surgery, where the use of mechanical valves or xenografts was controversial. Mechanical valves in the tricuspid position show a higher risk of thromboembolic complications and the use of biological valves in younger patients is accompanied with the risk of valve degeneration (Glower et al. 1995; Kaplan et al. 2002; Nakano et al. 2001).

When the tricuspid valve is seriously damaged or totally destroyed most often due to bacterial endocarditis (very often related to intravenous drug abuse), valve repair is extremely difficult or impossible. Moreover, the prosthetic valve implantation is associated with the risk of infection persistence and/or re-infection, especially when drug abuse continues postoperatively. Simple valve excision was also recommended (Arbulu et al. 1993). Radical excision and absence of any prosthetic material is beneficial, however, total tricuspid valve excision results in severe (usually fatal) tricuspid regurgitation. Only sporadic case reports or small cohorts of patients with tricuspid valve endocarditis, in whom MA were used in the tricuspid position, have been published (Acar et al. 1994; Hvass et al. 2001; Mestres et al. 1999; Pomar and Mestres 1993). So far the exact technique of MA fixation into the tricuspid position has not been worked out in an animal model. A reproducible technique of papillary muscle fixation and the optimal orientation of MA in the tricuspid position have not been evaluated yet.

We decided on an experimental study, as we needed to gain technical experience as well as the estimation of short- and long-term function of MA. Our aim was to verify whether the quality of sheep MA after harvesting and processing as per the protocol of our institutional human Cardiovascular Tissue Bank was adequate (Š patenka et al. 1997ab) and to develop a reproducible surgical technique for MA implantation, which would be applicable in clinical practice (Vojáček et al. 2006). Finally, we planned to investigate immediate postoperative function of the MA in the tricuspid position by means of epicardial echocardiography.

\section{Materials and Methods}

The experimental studies were performed according to the guidelines and practice established by the institutional Committee for Animal Care and Use, and in compliance with the legislation of the Czech Republic. All animals 
were cared for in compliance with the European Convention on Animal Care and the study was approved by the institutional Ethics Committee.

During the first stage of the experimental study 20 MAs were collected. Twenty sheep at the age of one year and weighing 23 to $36 \mathrm{~kg}$ were operated under general anaesthesia. Surgical exposure was achieved via anterolateral right thoracotomy, through the $5^{\text {th }}$ intercostal space. At first, all sheep underwent epicardial ultrasound examination using VIVID 7, VIVID 4, VIVID 3 ultrasound devices (GE Medical Systems with 7S, 5S probes). After performing a basic, comprehensive heart examination, the following 5 echocardiographic epicardial windows of the tricuspid valve were obtained.

1. 4-chamber window. This view is obtained by placing the probe on the inferolateral surface of the right atrium near the vena cava superior orifice in the horizontal plane.

2. Lateral right ventricular base window showing tricuspid and aortic orifice in long axis. This view is obtained after placement of the probe on the right ventricle near the atrioventricular groove laterally.

3. Medial right ventricular base window showing tricuspid and mitral orifice in long axis. This view is obtained after placement of the probe on the right ventricle near the atrioventricular groove medially.

4. Short axis inflow view showing tricuspid and mitral orifice in a short axis from the medial right ventricular base window by rotating the probe.

5. Right ventricular inflow/outflow window showing the tricuspid valve, RV outflow tract and pulmonary valve. This view is obtained by placing and rotating the probe on the right ventricle atrioventricular groove.

Afterward, the animals were euthanized by intravenous administration of Thiopentane (Thiopental, ICN, Czech Republic a.s. - $10 \mathrm{mg} / \mathrm{kg}$ ) and potassium chloride (Kalium Chloratum, Zentiva Ltd., Praha - $20 \mathrm{ml} / \mathrm{kg}$ ). Their hearts were explanted under sterile conditions; mitral valves were collected with rims of the left atrium and left ventricle and with the entire subvalvular apparatus, including both papillary muscles (Plate VI, Fig. 1). The anatomy of papillary muscles and the size of MA were evaluated using Hegar dilatators. MAs were processed as per the standard protocol of the Cardiovascular Tissue Bank, Transplant Centre, University Hospital Motol. They were deposited directly into the cultivation medium E 199 with the antibiotic cocktail - cefuroxime $0.2 \mathrm{mg} /$ $\mathrm{ml}$ (Zinacef, GlaxoWellcome) + piperacillin $0.2 \mathrm{mg} / \mathrm{ml}$ (Pipril, Lederle) + amikacin $0.1 \mathrm{mg} / \mathrm{ml}$ (Amikin, BristolMyers Squibb) + fluconazol $0.1 \mathrm{mg} / \mathrm{ml}$ (Diflucan, Pfizer). After $24 \mathrm{~h}$-storage at the temperature of $37.0^{\circ} \mathrm{C}$ these valves were kept at +5 to $+7^{\circ} \mathrm{C}$ for the period of $3-5$ days. Then they were transferred in a laminar flow box under sterile conditions into the cryoprotective solution (E 199 with 10\% dimethylsulphoxide) and sealed in plastic bags (Gambro Haemofreeze/Haemo bags NPBI BV DF 1200, the Netherlands) using two-layer technique. Finally, they were programme-cooled from the temperature of +10 to $-60{ }^{\circ} \mathrm{C}$ (at the rate of $-1{ }^{\circ} \mathrm{C} / \mathrm{min}$ ) and then stored in the liquid phase of liquid nitrogen $\left(-196^{\circ} \mathrm{C}\right)$ in a separate container.

Two to three adult sheep donors were bled out under the same technique of general anaesthesia to obtain enough sterile allogenic blood necessary for one MA transplant in recipient sheep.

Transplantation into the tricuspid position

In one month's time we implanted MAs in the experimental laboratory. MAs were removed from the container $30 \mathrm{~min}$ before operation and thawed in the same way as when using human allografts ( 15 min at room temperature followed by $15 \mathrm{~min}$ in a $37^{\circ} \mathrm{C}$ water bath).

Thirteen sheep, one year of age, 23 - $36 \mathrm{~kg}$ body mass, were narcotized with ketamine (Narkamon, Spofa a.s. - 10\% $5 \mathrm{mg} / \mathrm{kg}$ ), dexmedetomidin (Precedex, Abbott Logistics, B.V. - $50 \mu \mathrm{g} / \mathrm{kg}$ ) and atropine $2 \mathrm{mg}$ (Atropini sulfas monohydricus, Atropin, Hoechst-Biotika, Slovak Republic). Then all animals were intubated and ventilated mechanically. General anaesthesia was maintained with the intravenous continuous infusion of sufentanile (Sufenta, Janssen Pharmaceutica N.V.) and propofol (Diprivan, Fresenius KABI, Austria GMBH). The right femoral artery and the right internal jugular vein were cannulated for continual pressure monitoring. Thoracotomy was made in the fifth intercostal space to expose mediastinum. Pressures in the right atrium and pulmonary artery were invasively measured and recorded prior to establishing extracorporeal circulation (ECC). The sheep were given heparin $(2 \mathrm{mg} /$ $\mathrm{kg}$ ), pericardium was opened, the ascending aorta was cannulated for arterial perfusion and both venae cavae for venous drainage. We used $300 \mathrm{ml}$ crystalloid priming with 2 allogenic blood transfusion packs (450 $\mathrm{ml}$ each) and 250 $\mathrm{ml} 20 \%$ Manitol. The heart was arrested with an infusion of cold crystalloid cardioplegia given antegradely within the aortic root - St. Thomas II $(10 \mathrm{ml} / \mathrm{kg})$. The tricuspid valve was exposed through the right atriotomy and totally excised, including chordae tendineae and papillary muscles cut of at the base. After proper anatomical rotation of the MA (Plate VI, Fig. 2), both papillary muscles were anchored transmurally with polypropylene monofilament mattress suture (4/0 Prolene, Johnson \& Johnson) buttressed with Teflon pledgets into the free right ventricular wall. Then the MA annulus was sewn into the recipient's tricuspid annulus by continuous running suture with the same sewing material, so that the anterior leaflet of the MA faced the septum (Plate VII, Figs 3, 4). In the area adjacent to the septum, sutures were inserted through the retained rim of the tricuspid valve septal leaflet in order to prevent the injury to the $\mathrm{AV}$ node. Running suture of atriotomy was performed on the beating heart. After weaning from ECC, decannulation and haemodynamic stabilisation, the right atrial and pulmonary artery pressures were measured and recorded again. Subsequently, epicardial echocardiographic examination was performed with the focus on the anatomy and function of the MA in tricuspid position. From each window the probe was manipulated to obtain the clearest images of the MA in the tricuspid position with its subvalvular apparatus. Annular diameter was measured during ventricular diastole. The movement of mitral allograft cusps was analyzed in a 2D mode during the whole cardiac cycle. Colour Doppler and CW, PW Doppler assessments of the mitral allograft flow were performed. 
Finally, the animal was euthanized by intravenous injection of Thiopentane and potassium chloride and the heart was explanted. The right atrium and the right ventricle were opened in order to ensure easy access to the implanted allograft and to facilitate its examination from both sides, including the anchored papillary muscles. Then a simple pulling test was performed using monofilament sutures (Prolene 4/0, Johnson \& Johnson) in order to evaluate the mechanical quality of the tissue by estimating the tearing force of the annulus, the cusps and subvalvular apparatus, including papillary muscles.

\section{Results}

We found typical tricuspid valve anatomy with both papillary muscles well developed in all donor animals. According to Acar classification the papillary muscles were of types I, II or III. It facilitated the subsequent anchoring of papillary muscles stumps into the right ventricular wall (Acar et al. 1996). A simple pulling test performed by an experienced cardiac surgeon showed that the annulus, cusps, the chordae tendineae and papillary muscles of the cryopreserved MA were strong enough for implantation purposes.

The initial haemodynamic measurements (under general anaesthesia, but before the ECC) were as follows: the mean right atrial pressure was $9 / 2$ (4), and the mean pulmonary arterial pressure was 23/13 (18).

All MA implantations into the tricuspid position in the sheep model were uneventful. The average ECC time was $58 \mathrm{~min}(42-88)$, the cardioplegic heart arrest was 36 min (28 - 45). Mean blood transfusion requirement was $800 \mathrm{ml}$ of allogenic blood. Weaning from ECC was without severe problems in all animals, with mild or moderate inotropic support. It was necessary to perform defibrillation in two cases. In all sheep regular sinus rhythm was restored and no signs of atrio-ventricular block were recognized.

Other haemodynamic measurements were made after weaning from ECC: The mean right atrial pressure was $15 / 4$ (10), and the mean pulmonary artery pressure was $27 / 17$ (21). Right atrium pressure curves did not show any significant $\mathrm{V}$ wave, which would indicate MA regurgitation. Finally, epicardial ultrasound examination was performed. All allografts showed good function. In eight animals normal function was found without any insufficiency or stenosis. In three animals trace insufficiency was found and in two animals, mild MA insufficiency was found due to restriction of the posterior leaflet in one case and due to a large allograft in a small annulus in the second case.

\section{Discussion}

Our experiment was designed as a pilot study trying to answer questions that must be solved before the method can be introduced into the cardiovascular tissue bank and cardiac surgical practice. Sheep model seems to be sufficient from the surgical point of view and it is economically much more advantageous compared to e.g. primates.

Supervision of the veterinary surgeon was routine and not only a legislative requirement. He was responsible for the breeding protocol, preoperative evaluation and selection of suitable animals.

Obviously, veterinary surgeons have much more experience with cardiac surgery in smaller domestic animals, mainly dogs (Martin et al. 2002; Borenstein et al. 2004; Orton et al. 2001). Although there are only few reports in literature concerning the extracorporeal circulation technique in sheep (Holmberg and Olsen 1987), it is widely used as experimental model in developing suitable techniques for human medicine. We did not find any controversies when applying principles, techniques and protocols of human extracorporeal circulation in sheep.

Availability of blood volume replacement, e.g. allogenic blood transfusion was found to be essential to avoid hypovolaemia and anaemia in sheep after weaning from ECC. The diversity of blood groups in animals and the lack of commercially available blood-typing 
reagents make complete typing and matching difficult. There are seven genetic systems of red cell blood groups recognized in sheep - A, B, C, D, M, R and X (Pastoret et al. 1998) and systems $B$ and $R$ seem to be clinically the most important. The most serious adverse event of transfusion is acute haemolysis. Fortunately, this is rare in domestic animals. Generally, those having received repeated transfusions are at risk. We did not record any adverse transfusion reaction within our experiment.

To this day we do not have sufficient information regarding the experimental use of MA in the tricuspid position. Although Bernal et al. reported very good mid-term results when using fresh sheep MA, one-week mortality was higher: 42\% (9/20). This study was mainly focused on histological changes in explanted MAs. They found valve surface almost free of endothelial cells. Fibrotic connecting tissue produced by infiltrated recipient fibroblasts replaced original tissue. The function of MA was evaluated only by simultaneous right atrial/right ventricular pressure monitoring (Bernal et al. 1998).

In our experiment we evaluated the postoperative function of MA by means of echocardiography. Originally we aimed to compare all three possible approaches, but the best imaging was obtained by technically the easiest epicardial echocardiography, compared to transthoracic or transoesophageal. It eliminated almost all artifacts known from the transthoracic approach, particularly caused by the left lung (Kienle and Thomas 1995).

We recorded a statistically significant increase of right atrial pressure compared to the measurement prior to cardiopulmonary bypass. It can be hardly explained by MA dysfunction because we found good functional results by echocardiography and there were no $\mathrm{V}$ waves on postoperative right atrial pressure monitoring, either. Right atrial pressure changes were probably due to positive postoperative fluid balance and it could also be related to the previous cardioplegic arrest. There is also correlation to significant rise of pulmonary artery pressures in the post cardiopulmonary bypass period.

Implantation of MA into the tricuspid position was uneventful in our experiment. Right thoracotomy approach is optimal to expose the right heart, both venae cavae and the ascending aorta. There is usually one difference from human anatomy: the azygos vein in the sheep heart mostly leads to the inferior vena cava, very close to the right atrium. During the cardioplegic arrest, when the right atrium is opened, it is the cause of very heavy bleeding which makes the implantation more difficult.

In contrast to Bernal et al. (1998), we were trying to find an optimal surgical technique which would be reproducible. In our opinion the transventricular papillary muscles fixation is durable enough in a low pressure system and it enables us to find the proper position for good MA coaptation.

Having carried out this experiment, we can move to the next step, which is to test midterm durability of MA by echocardiography and magnetic resonance imaging, mechanical and histological tissue changes, including viability in one year survivals.

It was proved that MA, collected, processed, and stored according to the Cardiovascular Tissue Bank Protocol remained sufficiently mechanically strong for the implantation into the tricuspid position. It was demonstrated that the MA transplantation into the tricuspid position is feasible. The immediate postoperative haemodynamic performance of MA in the tricuspid position was excellent in all animals. The mid-term results are currently being evaluated.

\section{Transplantace mitrálního alograftu do trikuspidální pozice - ovčí experimentální model}

V naší práci jsme se soustředili na nalezení optimální techniky implantace mitrálního alograftu do trikuspidální pozice. Nejprve jsem připravili 20 kryopreservovaných mitrálních alograftů, které jsme postupně implantovali 20 ovcím cestou pravostranné thorako- 
tomie, za použití mimotělního oběhu s kardioplegickou srdeční zástavou. Domníváme se, že transventrikulární fixace papilárních svalů je nejvhodnější technika pro zajištění optimální geometrie a dlouhodobé životnosti alograftu. Funkci chlopně jsme verifikovali echokardiograficky jak před tak po implantaci. Tato vyšetření byla v souladu s hemodynamickými měřeními. Prokázali jsme, že mitrální alografty, které byly odebrány, zpracovány a uloženy podle protokolu naší kardiovaskulární tkáňové banky zůstávají dostatečně mechanicky kvalitní, aby je bylo možné implantovat do trikuspidální pozice. Dále jsme prokázali, že implantace mitrálního allograftu do trikuspidální pozice je možná a funkce implantovaných chlopní byla velmi dobrá u všech operovaných zvíŕat. V současnosti probíhá další fáze projektu, zaměřená na střednědobé výsledky, které by mohly naznačit použitelnost metody v humánní medicíně.

\section{Acknowledgement}

The study was supported by the Czech Ministry of Health Research Grant IGA MZCR No. NR9086-3-2006

\section{References}

ACAR C, IUNG B, CORMIER B, GRARE P, BERREBI A, D'ATTELLIS N, ACAR J, CARPENTIER A 1994: Double mitral homograft for recurrent bacterial endocarditis of the mitral and tricuspid valves. J Heart Valve Dis 3: 470-472

ACAR C, TOLAN M, BERREBI A, GAER J, GOUEZO R, MARCHIX T, GEROTA J, CHAUVAUD S, FABIANI JN, DELOCHE A, CARPENTIER A 1996: Surgery for acquired heart disease. J Thorac Cardiovasc Surg 111: 367-380

ARBULU A, HOLMES RJ, ASFAW I 1993: Surgical treatment of intractable right-side endocarditis in drug addicts: 25 years' experience. J Heart Valve Dis 2: 129-137

BERNAL JM, RABASA JM, CAGIGAS JC, VAL F, REVUELTA JM 1998: Behavior of mitral allografts in the tricuspid position in the growing sheep model. Ann Thorac Surg 65: 1326-1330

BODNAR E 1994: Editorial. Clinical use of homologous and heterologous mitral valves. J Heart Valve Dis 3 : 468-469.

BORENSTEIN N, DANIEL P, BEHR L, POUCHELON JL, CARBOGNANI D, PIERREL A, MACABET V, LACHEZE A, JAMIN G, CARLOS C, CHETBOUL V, LABORDE F 2004: Successful surgical treatment of mitral valve stenosis in a dog. Vet Surg 33: 138-145

GLOWER DD, WHITE WD, SMITH LR, YOUNG WG, OLDHAM HN, WOLFE WG, LOWE JE 1995: Inhospital and long-term outcome after porcine tricuspid valve replacement. J Thorac Cardiovasc Surg 109: $877-883$

HOLMBERG DL, OLSEN DB 1987: Anesthesia and cardiopulmonary bypass technique in calves and sheep. Vet Surg 16: 463-465

HUBKA M, SISKA K, BROZMAN M, HOLEC V 1966: Replacement of mitral and tricuspid valves by mitral homograft. J Thorac Cardiovasc Surg 51: 195-204

HVASS U, BARON F, FOURCHY D, PANSARD Y 2001: Mitral homografts for total tricuspid valve replacement: comparison of two techniques. J Thorac Cardiovasc Surg 121: 592-594

KAHN CM, LINE S, AIELLO SE (Eds.) 2006: The Merck Veterinary Manual on-line accessed on http://www. merckvetmanual.com/mvm/index.jsp?cfile=htm/bc/10300.htm on January 16, 2007

KAPLAN M, KUT MS, DEMIRTAS MM, CIMEN S, OZLER A 2002: Prosthetic replacement of tricuspid valve: bioprosthetic or mechanical. Ann Thorac Surg 73: 467-473

KIENLE RD, THOMAS WP 1995: Echocardiography. In: NYLAND TG and MATTOON JS (Eds.): Veterinary diagnostic ultrasound. Philadelphia, WB Saunders.

MARTIN JM, ORTON EC, BOON JA, MAMA KR, GAYNOR JS, BRIGHT JM 2002: Surgical correction of double-chambered right ventricle in dogs. J Am Vet Med Assoc 220: 770-774, 768

MESTRES CA, MIRO JM, PARE JC, POMAR JL 1999: Six-year experience with cryopreserved mitral homografts in the treatment of tricuspid valve endocarditis in HIV-infected drug addicts. J Heart Valve Dis 8: $575-577$

NAKANO K, ISHIBASHI-UEDA H, KOBAYASHI J, SASAKO Y, YAGIHARA T 2001: Tricuspid valve replacement with bioprostheses: long-term results and causes of valve dysfunction. Ann Thorac Surg 71: 105-109

ORTON EC, MAMA K, HELLYER P, HACKETT TB 2001: Open surgical repair of tetralogy of Fallot in dogs. J Am Vet Med Assoc 219: 1089-1093, 1073

PASTORET PP, GRIEBEL P, BAZIN H, GOVAERTS A (Eds.): 1998: Handbook of vertebrate immunology. $1^{\text {st }}$ ed. San Diego, Academic Press, 673 p. 
POMAR JL, MESTRES CA 1993: Tricuspid valve replacement using a mitral homograft. Surgical technique and initial results. J Heart Valve Dis 2: 125-128

ŠPATENKA J, HONĚK T, KOSTELKA M, HUČÍN B, FIŠER B, HÁJEK T, POVÝŠILOVÁ V, KOBYLKA P 1997a: Harvesting the heart for preparation of heart valve allografts. Rozhl Chir 76: 113-117 (in Czech, abstract in English)

ŠPATENKA J, KOSTELKA M, KOBYLKA P, HUČÍN B, HONĚK T, LOCHMAN O, HÁJEK T, TLÁSKAL T, POVÝŠILOVÁ V, FIŠER B 1997: Preparation, storage, transportation and use of heart valves for allotransplantation. Rozhl Chir 76: 118-125 (in Czech, abstract in English)

VOJÁČEK J, MOKRÁČEK A, ŠPATENKA J et al. 2006: Implantation of Cryopreserved Mitral Allograft into the Tricuspid Position in an Experimental Study in Sheep: Technical Aspects of Implantation and Immediate Results Evaluated by Epicardial Echocardiography. Zentralbl Chir 131: 511-516 

Plate VI

Mokráček A. et al.: Transplantation of ... pp. 89-95

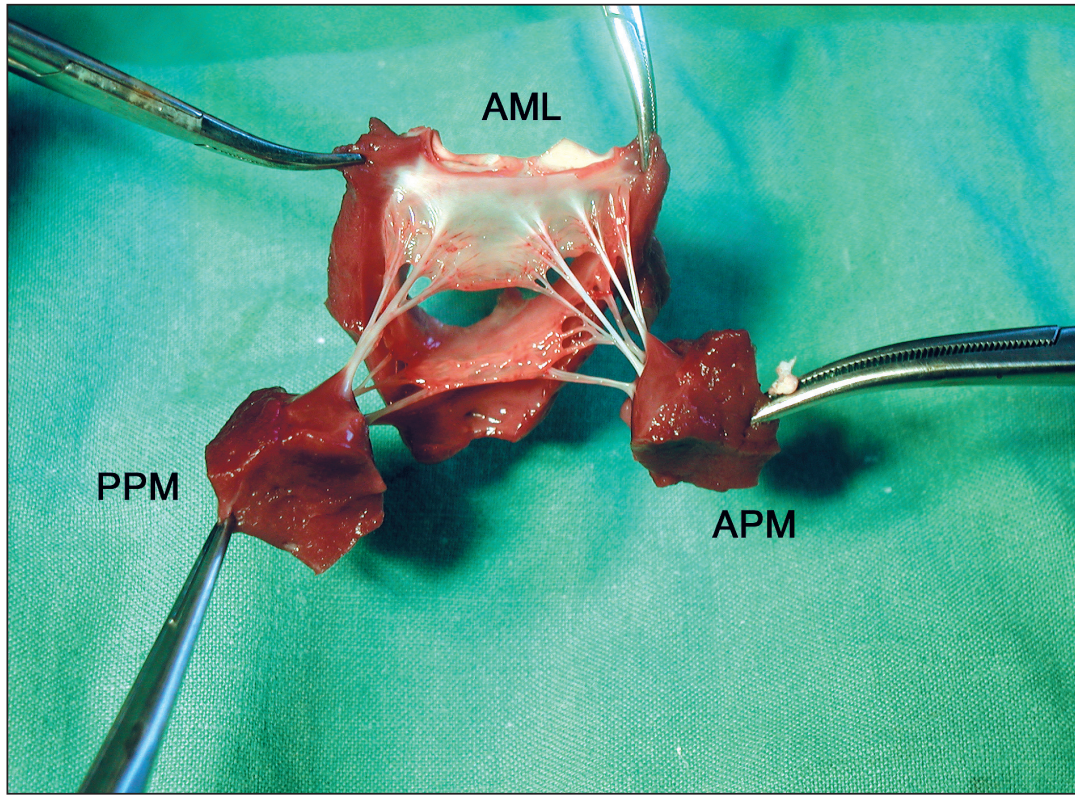

Fig. 1. Harvested mitral allograft with its entire subvalvular apparatus, including both papillary muscles (AML - anterior mitral leaflet, APM - anterolateral papillary muscle, PPM - posteromedial papillary muscle)

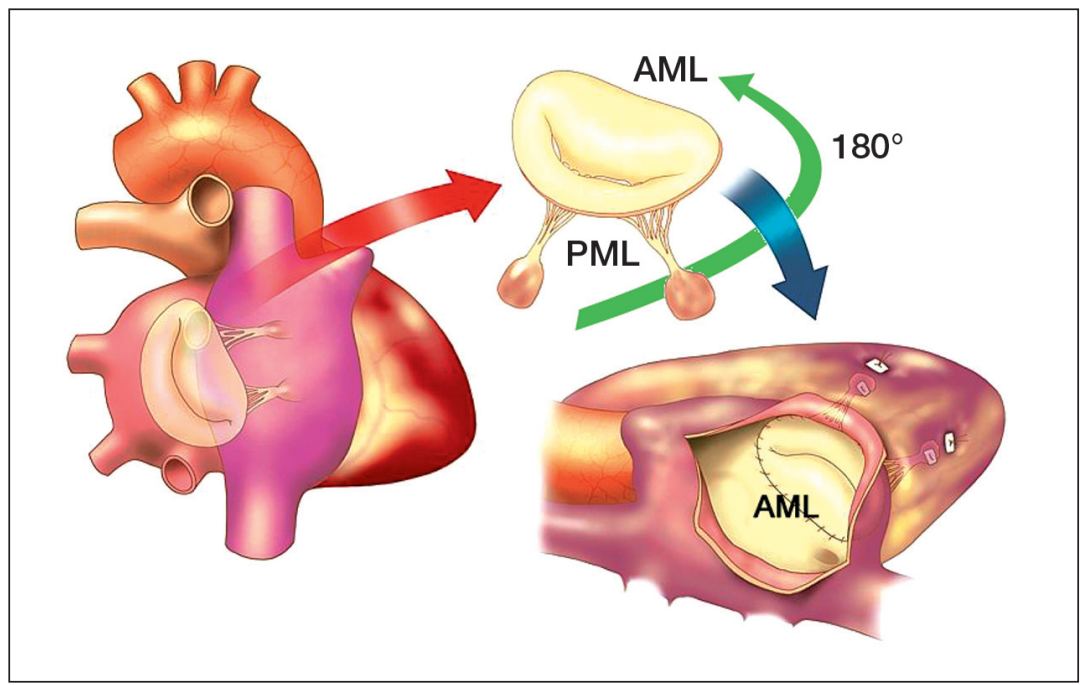

Fig. 2. Mitral allograft implantation scheme: After proper anatomical rotation of the mitral allograft (the anterior mitral leaflet was facing the septum), both papillary muscles were anchored by transmural polypropylene monofilament mattress suture buttressed with Teflon pledgets into the free right ventricular wall. Then the mitral allograft annulus was sewn into the recipient's tricuspid anulus by continuous running suture (AML - anterior mitral leaflet, PML - posterior mitral leaflet).

Scheme created by MUDr. Pavel Žáček, Division of Cardiac Surgery, University Hospital Hradec Králové 


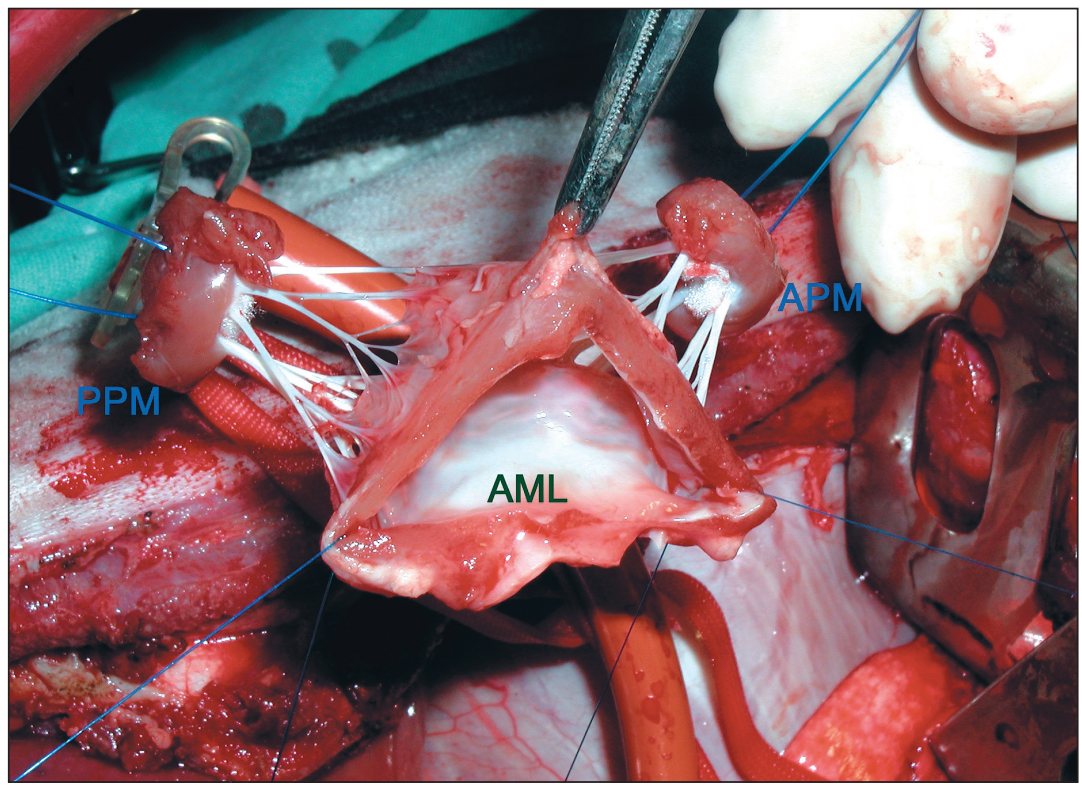

Fig. 3. The view of mitral allograft during implantation: There was one monofilament suture in each commissure and the anterior leaflet was orientated posteriorly. Both papillary muscles were prepared for transventricular fixation with polypropylene monofilament mattress suture buttressed with Teflon pledgets.

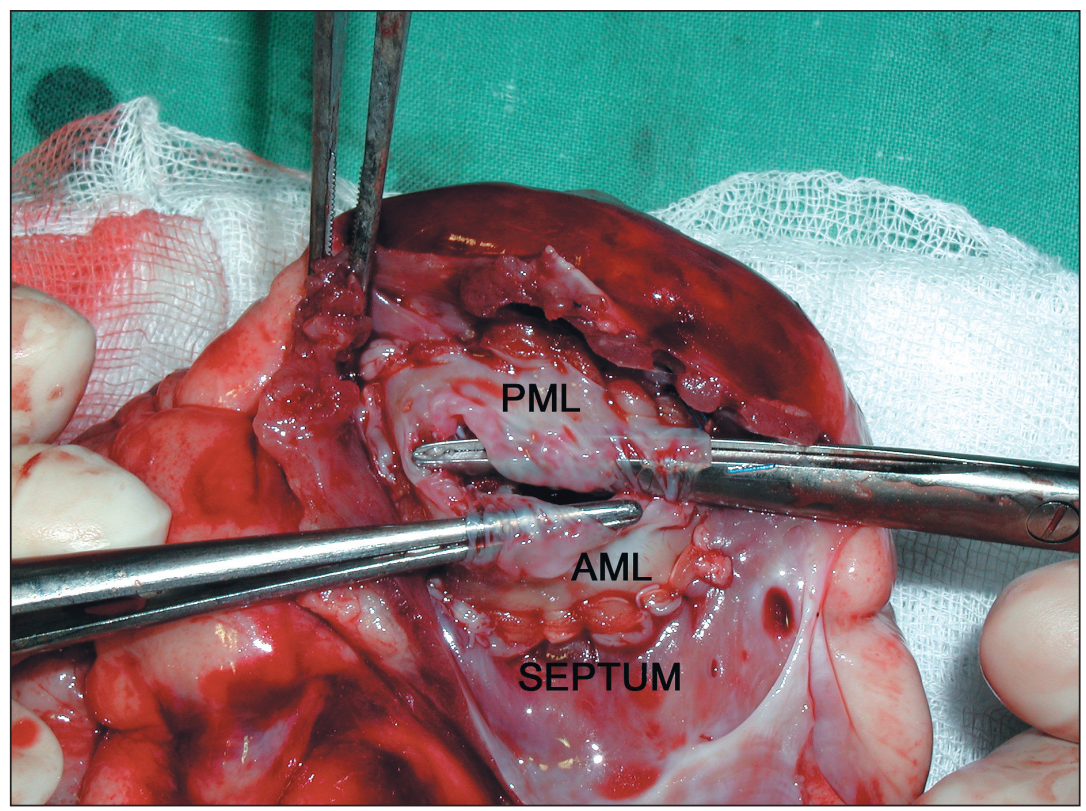

Fig. 4. Implanted mitral allograft (the view from the right atrium after heart explantation). Both leaflets were pulled up with two pairs of forceps showing a nice coaptation without leaflet prolaps or restriction. Anterior leaflet was orientated towards the septum (AML - anterior mitral leaflet, PML - posterior mitral leaflet). 